Bernard K.H. Pauw, M.D., * Miro S. Makek, M.D., ${ }^{\dagger}$

Ugo Fisch, M.D., and Anton Valavanis, M.D.

\title{
Preoperative Embolization of
}

Paragangliomas (Glomus Tumors)

\author{
of the Head and Neck: \\ Histopathologic and \\ Clinical Features
}

\begin{abstract}
Forty-eight surgical specimens were examined histologically and the case histories reviewed to determine the histopathologic features of embolized paragangliomas (glomus tumors) in relation to the time interval between embolization and surgery. Different degrees of thrombus formation and of multinucleated foreign body giant cells occurred during the first 7 days after embolization; thereafter, giant cells with active phagocytosis, fragmentation of embolic material, and partial revascularization were observed. Only one third of the tumor vessels were embolized. Complete obliteration of $40 \%$ of embolized vessels occurred more than 2 months postembolization. The histologic changes induced by embolization in paragangliomas of the head and neck may be classified in four stages. Histologically, the best time for surgery is within 8 days from embolization; surgery performed more than 8 days following embolization, however, is not compromised by revascularization. (Skull Base Surgery, 3(1):37-44, 1993)
\end{abstract}

Preoperative embolization of paragangliomas (glomus tumors) is widely used to devascularize glomus tumors in any location of the head and neck. ${ }^{1-10}$ The most commonly employed materials for embolization are Gelfoam and polyvinyl alcohol (PVA) foam. The use of Gelfoam is rather limited because of its rapid reabsorption rate. PVA (also known as Ivalon) is biocompatible, nonabsorbable, and, if used in microparticles of 200 to 500 $\mu \mathrm{m}$, causes effective tumor devascularization. ${ }^{4,5}$ Definitive thrombosis and hemorrhagic necrosis of several renal cortex arteries with no lysis or fragmentation of embolic material were found 7 days after embolization of renal arteries using PVA in dogs. ${ }^{11}$ Microscopic examination of human specimens removed after two fatalities, which occurred after embolization with PVA for symptomatic neonatal hepatic arteriovenous malformation, 12 revealed in one case intravascular giant cell reaction, medial and adventitial hypertrophy, and recanalization of the vascular lumen. A review of the literature failed to reveal further histopathologic studies on embolic agents. Therefore, the surgical specimens and the clinical data of 45 patients embolized and operated on at the ENT Department of the University of Zürich for head and neck paragangliomas were reviewed. The aim of this study was to determine the histopathologic changes occurring in the tumors after embolization and to correlate these with the clinical data.

Skull Base Surgery, Volume 3, Number 1, January 1993 ENT Department, University Hospital Zürich, Switzerland Bernard K.H. Pauw was supported by the Niels Stensen Stichting-Amsterdam while working in Zürich. *Present address: ENT Department, University Hospital Rotterdam, The Netherlands †Present address: Pathologie-Institut für bioptische Diagnostik, Zürich, Switzerland Reprint requests: Dr. Fisch, ENT Department, University Hospital Zürich, Rämistrasse 100, 8091 Zürich, Switzerland Copyright (C) 1993 by Thieme Medical Publishers, Inc., 381 Park Avenue South, New York, NY 10016. All rights reserved. 


\section{MATERIAL AND METHODS}

The study included 45 patients ( 20 males [mean age, 40 years; range, 18 to 57 years] and 25 females [mean age, 42 years; range, 14 to 71 years]) operated on because of 48 head and neck paragangliomas at the ENT department of the University Hospital Zürich between 1985 and 1989. Prior to surgery, all tumors had been embolized with PVA. ${ }^{6}$

\section{Clinical Data}

The operated tumors were divided according to localization into temporal (35), carotid (6), and vagal paragangliomas (7). Of these, 43 tumors were unifocal, and 5 tumors were of multifocal origin (one patient with a temporal and carotid body and another with temporal, carotid, and vagal tumors). Temporal paragangliomas were classified according to Fisch. ${ }^{6}$ The case histories of the patients were reviewed for the following parameters: time interval between embolization and surgery, previous treatment (radiotherapy, embolization), estimated operative blood loss, and operative time and length of postoperative hospitalization.

\section{Histopathology}

Representative specimens of the 48 tumors were fixed in $4 \%$ formalin and embedded in paraffin. The histologic sections of the tumors were stained with hematoxylin and eosin, Alcian blue, periodic acid-Schiff, and van Gieson elastin stains. The percentage of tumor vessels occluded by embolic material as well as the histologic changes taking place in them were determined from single representative sections. The amount of necrosis, edema, hemorrhage, inflammation, and fibrosis seen in tumor tissue were graded as:,,-+++ , and +++ .

The histologic examination was performed without knowledge of the clinical data.

\section{RESULTS}

\section{Clinical Findings}

\section{Classification of Tumors}

The 48 paragangliomas were divided in 35 temporal tumors, six carotid body tumors, and seven vagal tumors. The classification of the temporal glomus tumors was $\mathrm{B}-\mathrm{C}_{1}$ (one case), $\mathrm{C}_{1-2}$ (four cases), $\mathrm{C}_{2-3} \mathrm{De}_{1}$ (seven cases), and $\mathrm{C}_{2-4} \mathrm{De}_{1-2} \mathrm{Di}_{1-2}(23$ cases $)$.

\section{Interval Between Embolization and Surgery}

Most of the patients (35) were operated on during the first week after embolization, 11 of which after 2 days and seven after 8 to 16 days. Three patients had surgery after more than 2 months (Fig. 1); they $\left(\mathrm{a} \mathrm{C}_{3} \mathrm{De}_{2} \mathrm{Di}_{2}\right.$ temporal paraganglioma with occlusive hydrocephalus, $\mathrm{a} \mathrm{C}_{3} \mathrm{De}_{1}$ and $\mathrm{C}_{1}$ tumor) were operated on with a delay of 2 months because of intercurrent illness.

\section{Previous Radiotherapy}

Eight patients had radiotherapy (1 to 20 years) prior to surgery.

\section{Previous Embolization}

Ten patients were embolized elsewhere ( 2 months to 7 years before admission). All these patients underwent reembolization prior to surgery.

\section{Operative Blood Loss}

The mean operative blood loss was $1600 \mathrm{cc}$ for $\mathrm{B} \mathrm{C}_{1-2}$ tumors, $1410 \mathrm{cc}$ for $\mathrm{C}_{2-3} \mathrm{De}_{1}$ tumors, and $3423 \mathrm{cc}$ for $\mathrm{C}_{2-4}$

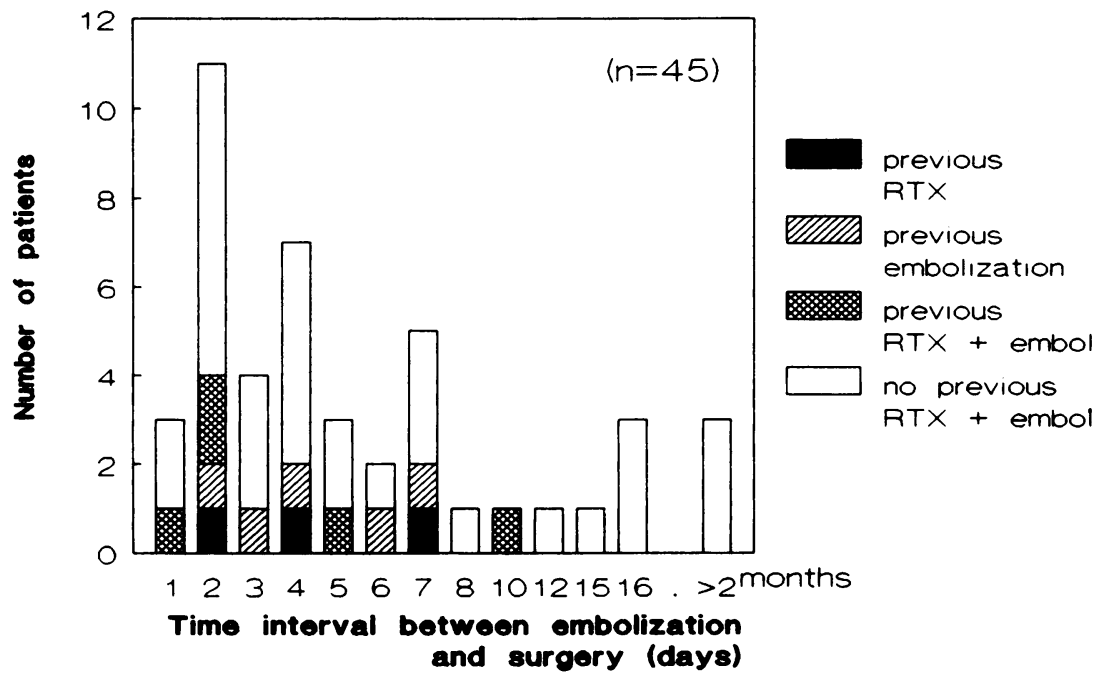

Figure 1. Number of patients and time interval between embolization (embol) and surgery. RTX: radiotherapy. 
Table 1. Time Interval Between Embolization and Surgery Less than 8 Days

\begin{tabular}{|c|c|c|c|c|c|c|c|}
\hline \multirow[b]{2}{*}{ Unifocal Paraganglioma } & \multirow[b]{2}{*}{ No. } & \multicolumn{2}{|c|}{$\begin{array}{c}\text { Intraoperative Blood } \\
\text { Loss (cC) }\end{array}$} & \multicolumn{2}{|c|}{$\begin{array}{c}\text { Operative Time } \\
\text { (hours) }\end{array}$} & \multicolumn{2}{|c|}{$\begin{array}{c}\text { Postoperative } \\
\text { Hospitalization } \\
\text { (days) }\end{array}$} \\
\hline & & Mean & Range & Mean & Range & Mean & Range \\
\hline \multicolumn{8}{|l|}{ Temporal } \\
\hline $\mathrm{B} \mathrm{C}_{1-2}$ & 3 & 1600 & $1000-2800$ & 6.00 & $5.20-6.30$ & 12 & $11-13$ \\
\hline $\mathrm{C}_{2-3} \mathrm{De}_{1}$ & 5 & 1410 & $350-3200$ & 5.43 & $3.00-8.10$ & 10 & $8-16$ \\
\hline $\mathrm{C}_{2-4} \mathrm{De}_{1-2} \mathrm{Di}_{1-2}$ & 20 & 3424 & $1000-9000$ & 7.00 & $5.15-9.30$ & 18 & $10-70$ \\
\hline Carotid body & 3 & 800 & $200-2000$ & 5.25 & $2.25-10.30$ & 11 & $9-13$ \\
\hline Vagal & 3 & 1067 & $1000-1200$ & 5.56 & $4.55-6.30$ & 22 & $10-28$ \\
\hline
\end{tabular}

$\mathrm{De}_{1-2} \mathrm{Di}_{1-2}$ tumors, operated on within 8 days after embolization (Table 1). The mean blood loss was of $800 \mathrm{cc}$ for unifocal carotid body tumors and $1067 \mathrm{cc}$ for vagal paragangliomas.

When the interval was 8 days or more, the mean blood loss was $650 \mathrm{cc}$ for $\mathrm{B} \mathrm{C}_{1-2}$ tumors, $2000 \mathrm{cc}$ for a $\mathrm{C}_{2-3}$ $\mathrm{De}_{1}$ tumor, and $1050 \mathrm{cc}$ for $\mathrm{C}_{2-4} \mathrm{De}_{1-2} \mathrm{Di}_{1-2}$ tumors; $200 \mathrm{cc}$ for a carotid body and $1267 \mathrm{cc}$ for vagal paragangliomas (Table 2).

\section{Operative Time}

The mean operative time for all categories of temporal paraganglioma varied from 5 hours and 40 minutes to 8 hours. The mean operative time for unifocal carotid body tumors varied from 2-1/2 to 5 hours and 25 minutes and for glomus vagal tumors from 5 hours 25 minutes to five hours 56 minutes (Tables 1 and 2).

\section{Postoperative Hospitalization}

The mean postoperative hospitalization for all categories of glomus temporale tumors varied from 10 to 19 days (Tables 1 and 2). The mean hospital stay varied from 11 to 24 days for unifocal carotid body tumors and from 12 to 22 days for vagal paragangliomas.

\section{Histopathologic Findings}

PVA alone or with thrombus formation occluded $30 \%$ (range, 5 to $80 \%$ ) of the tumor vessels in a representative section of each tumor. The embolic material was present in arterial vessels of different sizes in and outside of the tumor, but not in capillaries. Proliferation of the intima began 2 days after embolization in some specimens. A more advanced intima-proliferation with ingrowth of fibroblasts appeared after 8 days or more. Fibrosis of the intima was only seen in two cases after previous radiotherapy ( 1 to 20 years before surgery).

Thrombus formation was present in all cases. The thrombi showed different degrees of organization 2 to 7 days after embolization. In early thrombus formation, the lumen of the vessels was filled with embolic material, numerous erythrocytes, neutrophilic leukocytes, and a loose network of fibrin (Fig. 2A). One to 2 days later, shrinkage and consolidation of the fibrin as well as proliferation of the intima starting from the periphery of the vessel were present (Fig. 2B). Organization and consolidation of the thrombi were complete after 7 days. In these thrombi, first mononucleated (Fig. 3A) and later on multinucleated giant cells (Fig. 3B) were seen 3 days from embolization. At the same stage, ingrowth of fibroblasts and infiltration of leukocytes into the thrombi were found, resulting in a solid obstruction of the lumen of the vessel. The giant cells appeared to be aggressive and phagocytosis of small and large parts of embolic material was found 5 days after embolization. In some cases parts of PVA were found in the cytoplasma of the giant cells (Fig. 4A). Eight days after embolization, fragmentation of PVA, proliferation, and ingrowth of capillaries into embolic material were also seen. At this stage, revasculariza-

Table 2. Time Interval Between Embolization and Surgery 8 Days or More

\begin{tabular}{|c|c|c|c|c|c|c|c|}
\hline \multirow[b]{2}{*}{ Unifocal Paraganglioma } & \multirow[b]{2}{*}{ No. } & \multicolumn{2}{|c|}{$\begin{array}{l}\text { Intraoperative } \\
\text { Blood Loss (cc) }\end{array}$} & \multicolumn{2}{|c|}{$\begin{array}{c}\text { Operative Time } \\
\text { (hours) }\end{array}$} & \multicolumn{2}{|c|}{$\begin{array}{c}\text { Postoperative } \\
\text { Hospitalization } \\
\text { (days) }\end{array}$} \\
\hline & & Mean & Range & Mean & Range & Mean & Range \\
\hline \multicolumn{8}{|l|}{ Temporal } \\
\hline $\mathrm{B} \mathrm{C}_{1-2}$ & 2 & 650 & $300-1000$ & 4.00 & $3.00-5.00$ & 12 & $10-13$ \\
\hline $\mathrm{C}_{2-3} \mathrm{De}_{1}$ & 1 & 2000 & & 8.00 & & 17 & \\
\hline $\mathrm{C}_{2-4} \mathrm{De}_{1-2} \mathrm{Di}_{1-2}$ & 2 & 1050 & $500-1600$ & 5.40 & $4.50-6.30$ & 19 & $12-26$ \\
\hline Carotid body & 1 & 200 & & 2.30 & & 24 & \\
\hline Vagal & 3 & 1267 & $300-2000$ & 5.25 & $4.30-6.25$ & 12 & $8-15$ \\
\hline
\end{tabular}


A
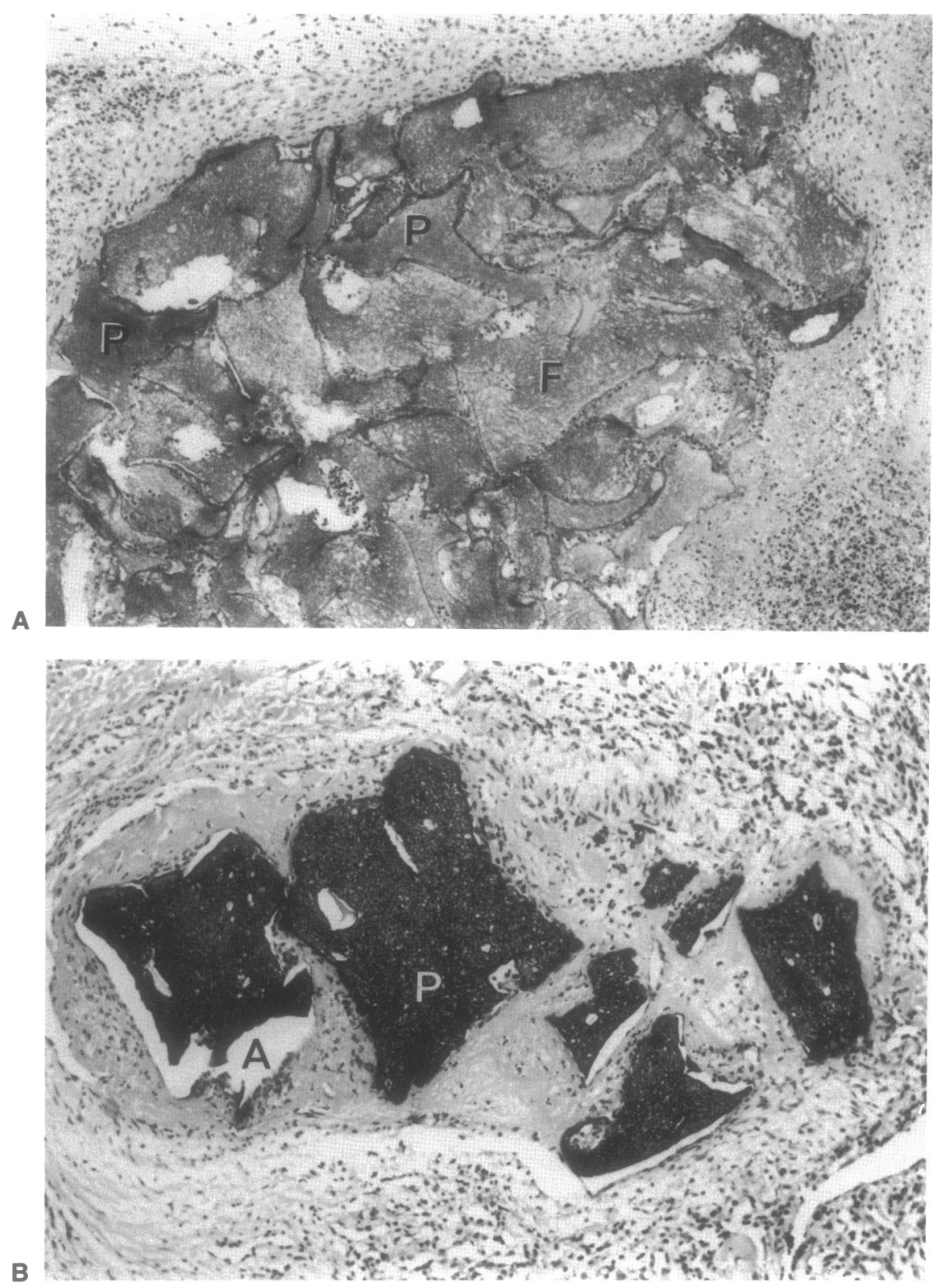

Figure 2. Stage 1: 1 to 2 days after embolization. A: Embolized vessel filled with PVA (P), erythrocytes, neutrophilic leukocytes, and loose fibrin network (F). (Hematoxylin and eosin; $\times 63$.) B: Shrunken fresh thrombus surrounding PVA (P). Intima proliferation is starting from the periphery of the vessel; clefts are artefacts (A). (Hematoxylin and eosin; $\times 80$.) tion, which was characterized by clefts filled with erythrocytes (Fig. 4B), was observed in $30 \%$ of the embolized vessels. Fragmentation of embolic material and complete obliteration of the lumen of the vessels with acellular, hyalinized fibrous tissue were observed in $40 \%$ of the embolized vessels 2 months after embolization. Many obliterated vessels showed also a lumen lined with endothelium next to the hyalinized and organized thrombus (Fig. 5A). Sometimes, PVA of reembolization was found in revascularized thrombus (Fig. 5B). These changes did not occur within 18 days from embolization.

Myxoid degeneration of the wall of vessels was found in six specimens; all had previous radiotherapy.

In more than half of the tumors, necrosis ( 32 specimens), edema (26 specimens), hemorrhage (24 specimens), and inflammation (34 specimens) were found (Table 3). As expected, the reaction of tumor tissue on isch- emia is more manifest between 3 and 8 days than immediately after embolization. These histologic features were not noted in the three specimens obtained more than 2 months after embolization. Fibrosis was only found in nine tumors having had embolization combined with radiotherapy.

\section{DISCUSSION}

\section{Histology}

The fact that only one third of the vessels was found to be embolized with PVA alone or together with thrombus formation in representative sections of each tumor is probably due to many variables, such as the size of the microparticle, the diameter of the vessel, the pressure used for 
Figure 3. Stage 2: 3 to 8 days after embolization. A: Differentiation of mononucleated giant cells (arrow) on the surface of PVA (P). (Hematoxylin eosin; $\times 250$.) B: Consolidated fibrin network $(F)$ infiltrated by differentiated, multinucleated giant cells (arrow), monocytes, ingrowing fibroblasts, and endothelial cells. (Hematoxylin and eosin; $\times 320$.)
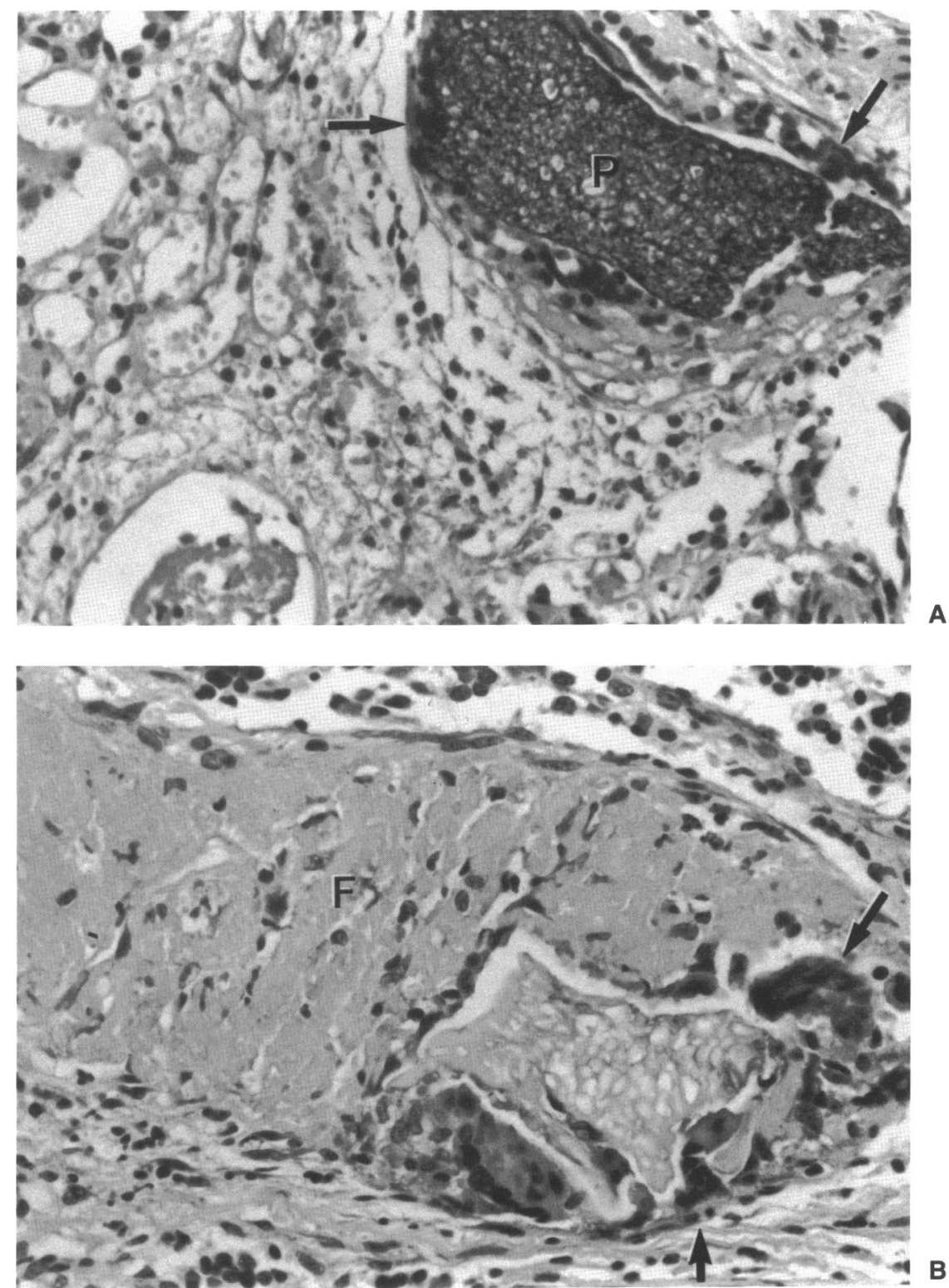

embolization, and the level of histologic section examined. These variables explain the wide variation in efficiency of the embolization. No interpretations of the blood flow in the nonembolized vessels are possible from this histologic study. Moreover, $83 \%$ of types $\mathrm{C}$ and $\mathrm{D}$ glomus temporale tumors are multicompartmental ${ }^{4}$ and therefore some parts of the tumor may escape embolization. Since only selected sections of the tumor were available, the multicompartmental aspects of the tumors were not included in this study.

The main histologic changes observed after embolization were: (1) thrombus formation with ingrowth of fibroblasts and multinucleated foreign body giant cells and (2) revascularization of arterial tumor vessels. Similar findings were published in previous studies. 4,11-13 However, phagocytosis of giant cells, fragmentation of PVA particles and the acellular, hyalinized obliteration of tumor vessels in late stages after embolization were not described before. The degree of occlusion of embolized vessels will diminish as the result of phagocytosis and fragmentation of PVA particles. However this vascularization process is partial and only involved $30 \%$ of the embolized vessels. The other thrombosed vessels undergo complete obliteration.

According to our study, four histologic postembolization stages can be identified:

Stage I (early thrombus formation): 2 days after embolization is characterized by thrombus formation.

Stage II (complete thrombus formation): 3 to 7 days after embolization there is proliferation of the intima into the vessels, ingrowth of fibroblasts in consolidated and organized thrombi, and appearance of multinucleated foreign body giant cells with active phago 
A
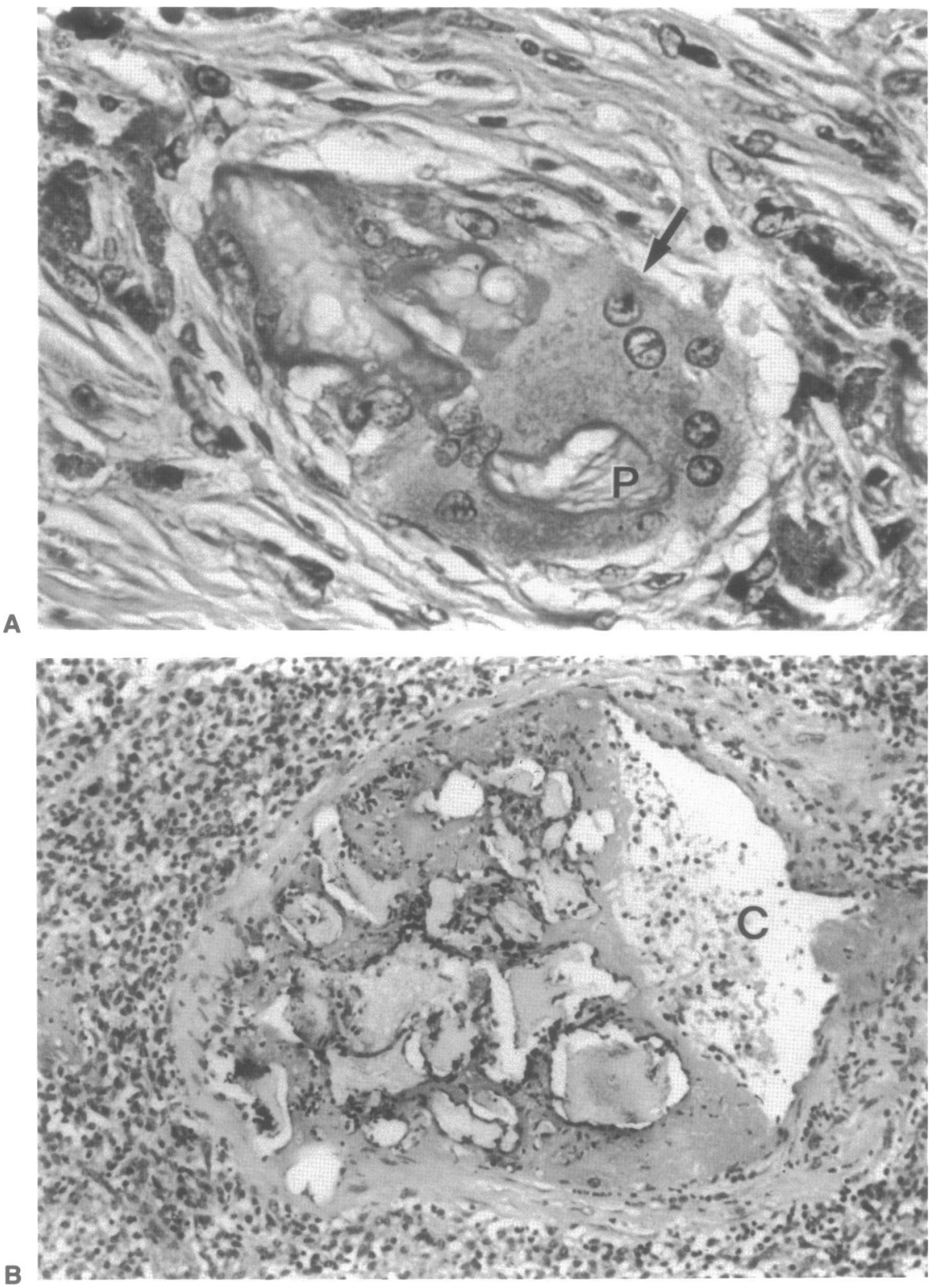

Figure 4. Stage 3: 9 to 16 days after embolization. A: Active phagocytosis of giant cells resulting in fragmentation of PVA (P). Arrow: large triangle-shaped giant cell with PVA in cytoplasma. (Hematoxylin and eosin; $\times 500$.) B: Vessel lumen containing highly fragmented, loosened PVA with confluent clefts (C) filled with erythrocytes, reestablishing circulation. (Hematoxylin and eosin; $\times 100$.) cytosis. The lumen of the vessel is totally obstructed by cellular elements, consolidated fibrin network and embolic material, still without any sign of revascularization.

Stage III (partial revascularization; 9 to 16 days postembolization): The embolization particles undergo fragmentation and inclusion in cytoplasma of multinucleated giant cells. Of the embolized vessels, $30 \%$ undergo partial revascularization.

Stage IV (complete obliteration: more than 2 months postembolization): Of the embolized vessels, $40 \%$ are completely obliterated but still present, in many instances, with an endothelial lining, and $30 \%$ of the vessels are still partially revascularized.

\section{Clinical Findings}

Most of the patients had surgery within 8 days from embolization. The mean blood loss was largest for temporal paraganglioma and lowest for unifocal carotid body tumors. The blood loss for temporal paraganglioma correlated to the size of the tumors $(\mathrm{C} 3>\mathrm{C} 2>\mathrm{Cl})$. The mean blood loss for type $\mathrm{B}$ and $\mathrm{C}$ tumors $(650$ and $1600 \mathrm{cc}$ ) is not much different from earlier reported findings. ${ }^{10}$ Murphy and Brackmann ${ }^{10}$ found a mean blood loss of $822 \mathrm{cc}$ in 5 patients with embolized type D tumors. This was even lower than the mean blood loss for eight embolized C2 patients $(925 \mathrm{cc})$. In contrast to these findings, the largest blood loss in our study was found in type $D_{i}$ tumors 
Figure 5. Stage 4: more than 2 months after embolization. A: Obliterated, hyalinized vessels (V), showing revascularized lumina lined with endothelium ( $R L)$, surrounded by vital tumor tissue (T). (Hematoxylin and eosin; $\times 200$.) B: PVA (P) can also be seen in revascularized vessels (V), if tumors with fully organized thrombus are reembolized later on. (Hematoxylin and eosin; $\times 80$.)
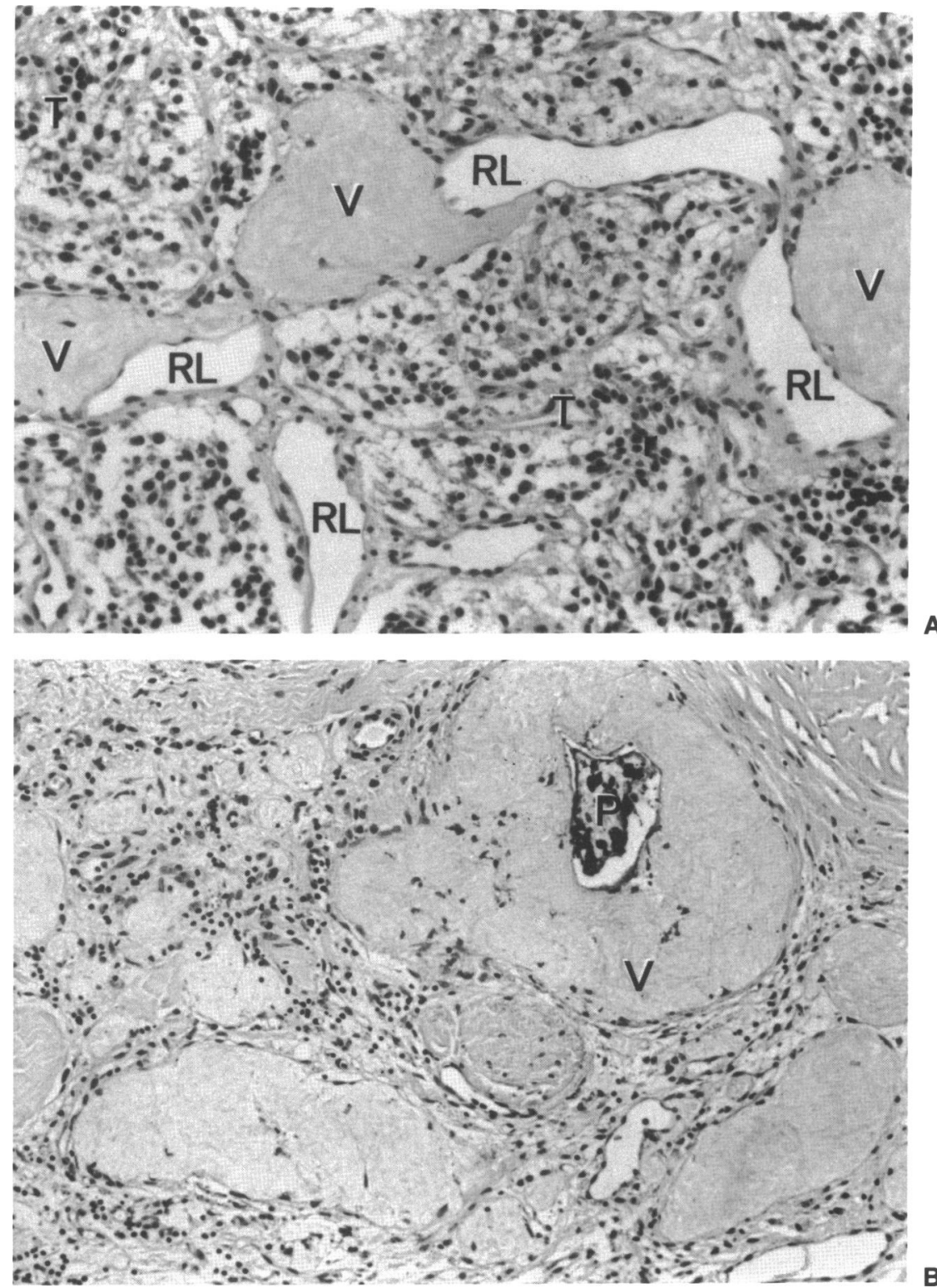

B

Table 3. Histopathologic Findings

\begin{tabular}{|c|c|c|c|c|c|c|c|c|c|c|c|c|c|}
\hline \multirow[b]{2}{*}{$\begin{array}{l}\text { Histopathologic } \\
\text { findings }\end{array}$} & \multicolumn{3}{|c|}{$\begin{array}{c}1-2 \text { Days } \\
\text { Postembolism } \\
(n=14)\end{array}$} & \multirow[t]{2}{*}{ Total } & \multicolumn{3}{|c|}{$\begin{array}{c}\text { 3-8 Days } \\
\text { Postembolism } \\
(n=24)\end{array}$} & \multirow[t]{2}{*}{ Total } & \multicolumn{3}{|c|}{$\begin{array}{c}>8 \text { Days } \\
\text { Postembolism } \\
(n=10)\end{array}$} & \multirow[t]{2}{*}{ Total } & \multirow[t]{2}{*}{ Total } \\
\hline & + & ++ & +++ & & + & ++ & +++ & & + & ++ & +++ & & \\
\hline Necrosis & 4 & 5 & 3 & 12 & 6 & 4 & 9 & 19 & 1 & 1 & - & 2 & 33 \\
\hline Edema & 2 & 4 & 2 & 8 & 7 & 3 & 7 & 17 & - & 1 & - & 1 & 26 \\
\hline Hemorrhage & 4 & - & 4 & 8 & 6 & 1 & 8 & 15 & 1 & 一 & - & 1 & 24 \\
\hline Inflammation & 6 & 3 & 2 & 11 & 6 & 6 & 6 & 18 & 4 & 1 & - & 5 & 34 \\
\hline Fibrosis & - & 1 & 1 & 2 & - & 3 & 1 & 4 & - & 1 & 2 & 3 & 9 \\
\hline
\end{tabular}


(mean, $3423 \mathrm{cc}$ ). This was expected, since paragangliomas with intradural extension, in which the anterior (AICA) of posterior inferior cerebellar arteries (PICA) supply the lesion, are almost never amenable to embolization. 4

There was no difference between the mean operative time needed for removal of temporal and vagal paragangliomas (approximately 6 hours). The shortest operative time (approximately $2 \frac{1}{2}$ hours) was found in unifocal carotid body tumors. The mean duration of postoperative hospitalization varied from 10 to 24 days for all categories of paragangliomas. No correlation was found between operative blood loss, operative time, postoperative hospitalization, and the time delay from embolization. Although a statistical analysis of the limited number of cases is impossible, the clinical material does not show evidence that it is not disadvantageous to operate before revascularization begins. Nevertheless, we prefer to operate as soon as possible after embolization. The long delays that occurred between embolization and surgery in our cases were mainly due to scheduling problems involving patients referred from outside the country.

\section{CONCLUSIONS}

1. The histologic changes induced by embolization in paragangliomas of the head and neck may be classified in four stages.

Stage 1 ( 1 to 2 days postembolization): Early thrombus formation.

Stage II ( 3 to 8 days postembolization): Complete thrombus formation and phagocytosis.

Stage III (9 to 16 days postembolization): Partial revascularization of $30 \%$ of embolized vessels and fragmentation of embolic material.

Stage IV (more than 2 months postembolization): Complete obliteration of $40 \%$ of embolized vessels.

2. Embolization with PVA (200 to $500 \mu \mathrm{m})$ occludes one third of the tumor vessels.
3. Revascularization is partial and only involves $30 \%$ of the embolized vessels.

Histologically, the best time for surgery is within 8 days from embolization; surgery performed more than 8 days following embolization, however, is not compromised by revascularization.

\section{REFERENCES}

1. Schick PM, Hieshima GB, White RA, et al: Arterial catheter embolization followed by surgery for large chemodectoma. Surgery, 87:459-464, 1980

2. Simpson GT, Konrad HR, Takahashi M, House J: Immediate postembolization excision of glomus jugulare tumors. Arch Otolaryngol 105:639-643, 1979

3. DuBois J, Kelly W, McMenamin P, McMenamin P, Macbeth GA: Bilateral carotid body tumors managed with preoperative embolization: A case report and review. J Vasc Surg 5:648-650, 1987

4. Lasjaunias P, Berenstein A: Endovascular treatment of craniofacia lesions. In: Surgical Neuroangiography, vol II. Berlin: Springer, 1987

5. Valavanis A: Preoperative embolization of the head and neck: Indications, patient selection, goals and precautions. AJNR 7 927-936, 1986

6. Fisch U, Mattox D: Microsurgery of the Skull Base. New York Thieme Medical Publishers, 1988

7. Ward PH, Chen Liu, Vinuela F, Bentson JR: Embolization: An adjunctive measure for removal of carotid body tumors. Laryngoscope 98:1287-1291, 1988

8. Young NM, Wiet RJ, Russell EJ, Monsell EM: Superselective embolization of glomus jugulare tumors. Ann Otol Rhinol Laryngol 97:613-620, 1988

9. Robison JG, Shagets FW, Beckett WC, Spies JB: A multidisciplinary approach to reducing morbidity and operative blood loss during resection of carotid body tumor. Surg Gynecol Obstet 168:166-170, 1989

10. Murphy TP Brackmann DE: Effects of preoperative embolization on glomus jugulare tumors. Laryngoscope 99:1244-1247, 1989

11. Tadavarthy SM, Moller JH, Amplatz K: Polyvinyl alcohol (Ivalon)-a new embolic material. Am J Roentgenol, 125:609-616, 1975

12. Repa I, Moradian GP, Dehner LP, Tadavarthy SM, Hunter DW, Castaneda-Zuniga WR, Wright GB, Katkov H, Johnson P, Chrenka B, Amplatz K: Mortalities associated with use of a commercial suspension of polyvinyl alcohol. Radiology 170: 395-399, 1989

13. Hawthorne MR, Makek MS, Harris JP, Fisch U: The histopathological and clinical features of irradiated and nonirridiated temporal paragangliomas. Laryngoscope 98:325-331, 1988 